\title{
COMPARATIVE UTILIZATION OF SEWAGE SLUDGE, POULTRY \\ DROPPINGS AND GROUNDNUT CAKE RATIONS BY WEST AFRICAN DWARF GOATS
}

\author{
*OKAGBARE G.O. AND AKINSOYINU A.O.
}

Department of Animal Science, University of Ibadan, Ibadan; Oyo State, Nigeria
Received 30 September 1997; Accepted 09 August 1998

\section{ABSTRACT}

Eighteen young West African dwarf (WAD) goats were used to compare the utilization of sewage sludge, poultry droppings and groundnut cake rations by WAD goats.

Total dry matter intake of the animals fed diet $A$ (groundnut cake based ration) and $C$ (poultry droppings based ration) was significantly $(P<0.05)$ higher than dry matter intake of animals fed diet $B$ (dry activated sewage sludge based ration). Total dry matter intake of animals fed diet $A(664.6 \mathrm{~g} /$ day) appeared to be higher than those fed diet $\mathrm{C}$ (600.5y/day), although the differences observed were not significant. Values observed for apparent dry matter, ether extract and nitrogen-free extract digestibilities between animals fed the different diets were not signiticant $(P>0.05)$. Crude fibre and crude protein digestibility values however varied appreciably. Values recorded (12.(1), 1.04 and $10.42 \mathrm{~g} / \mathrm{day} ;$ and $3.13, \quad 0.28$ and 2.72 g/day $/ W^{0.75}$ Kg for animals fed diets $A, B$, and C respectively) for nitrogen balance and weight gains (56.8, -2.7 and $36.8 \mathrm{~g} / \mathrm{day}$ for animals fed diets $A, B$ and $C$ respectively) were higher for animals fed diet $A$, followed by animals fed diets $C$ and $B$ respectively.

Keywords: Protcin utilization, groundnut cake, poultry droppings, scwage sludge, WAD goats.

\section{INTRODUCTION}

In the preparation of goat ration, the protein sources is one of the most expensive ingredient. The prices of fish meal and groundnut cake, the conventional sources of

* Iresent Address: Department of Animal Sejence. Delia

State University, Asaba Campis, Asaba. Delta State. protcin in livestock ration, have risen exhorbitantly in recent times, thus making the search for alternative sources of protein imperative.

The utilization of non-protein nitrogen by ruminants gives them a special advantage. Dicts containing poultry waste have been fed to cattle (Harmon, Fontenot and Wcbb, 1975 and Smith, 1973, Balewu and Adeneye 1996); Shecp (Hamblin, 1980, Kanc and Paliev, 1981; Adcyemo, 1984; Adegbola, Smith and Okcudo, 1990; Taiwo, Adebowale, Akinsoyinu and Grecnhalgh, 1995, Adebowale and Taiwo, 1996) and goats (Abasickong, 1987; Adcbowale and Taiwo, 1996). Activated Sewage sludge has also been used in compounding ration for catte (Sridhar and Pillai, 1973; Bertrand, 1980) and sheep (Hackler, Heuman, Hatficld and Johnson, 1957).

Presently, poultry wastes and activated sewage sludge have not attracted any market value and information on their use in goat ration is limited. The inclusion of activatcd scwage sludge and poultry wastes in goat ration, will serve as a means of disposing the huge amount of these wastes, a reduction in environmental pollution, decrease feed cost and increase the supplies of available nitrogen and essential mineral sources. The study was therefore designed to investigate the possible utilisation of activated sewage sludge and pesultry droppings in goat ration.

\section{MATERIALS AND METHODS}

Eightecn West African dwarf goats aged 5 6 months and weighing $5.3-6.4 \mathrm{~kg}$ were used for the experiment. The eighteen animals were equally divided at random into three groups - A, B and C. The animals were dewormed with Thiobendazone at the beginning of the study. 
TABLE 1: PERCENTAGE COMPOSITION OF EXPERIMENTAL DIETS

\begin{tabular}{|c|c|c|c|}
\hline \multirow[t]{2}{*}{ INGFREIENTS } & \multicolumn{3}{|c|}{ IMETS } \\
\hline & $\wedge$ & $\mathbf{B}$ & c: \\
\hline Cassina fikur & 49.5 & 37.6 & 32.5 \\
\hline I) ried Activalcd Sewage Sluigge & $\cdot$ & 37.5 & - \\
\hline Poult ry I toppings & - & . & 42.6 \\
\hline Cirrundnul Cakc & 251 & - & - \\
\hline 1)ricd Brewers (irain & $25.1)$ & 25.9 & 25.9 \\
\hline *Vitamin - Mincrat Mixture & 1,25 & 0.25 & 0.25 \\
\hline Commonn Salt & 1.25 & 0.25 & 0.25 \\
\hline Calculated Cruode Protein (\%) & 14 & 14 & 14 \\
\hline Total & 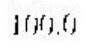 & $J(k) . f j$ & $1(6), 0)$ \\
\hline
\end{tabular}

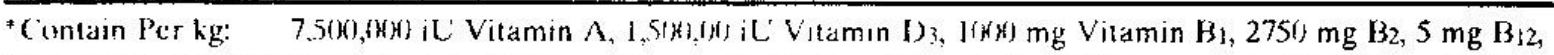

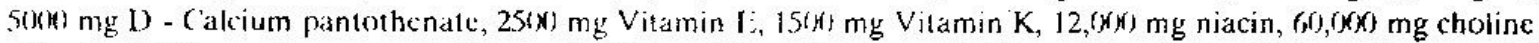
chloride, $5000 \mathrm{mg}$ ethexyquin, $16,130 \mathrm{mg} \mathrm{KJ}, 286 \mathrm{mg}$ Cobalt Sulphate, 12,5\%)mg Zinc Oxide, $1283 \mathrm{mg}$ Copper oxide, $20,323 \mathrm{mg}$ Ferric carbunate.

\section{TABLE 2: PROXIMATE CHEMICAL COMPOSITIONS ( $g / 100 \mathrm{~g}$ DM) OF EXPERIMENTAL DIETS}

\begin{tabular}{|c|c|c|c|c|c|c|}
\hline \multirow[t]{2}{*}{ Diets } & \multirow[b]{2}{*}{$\begin{array}{l}\text { Dry } \\
\text { Matlex }\end{array}$} & \multirow[b]{2}{*}{$\begin{array}{l}\text { Crude } \\
\text { protein }\end{array}$} & \multicolumn{2}{|c|}{ Nutrient Composition } & \multirow[b]{2}{*}{$\begin{array}{l}\text { Nitrogen } \\
\text { free extract }\end{array}$} & \multirow[b]{2}{*}{ Ash } \\
\hline & & & $\begin{array}{l}\text { Crude } \\
\text { fibre }\end{array}$ & Eilher exiracl & & \\
\hline Diet $A$ & 94.0 & 14.4 & 9.5 & 2.11 & 68.1 & 6 \\
\hline Diet $B$ & 97.0 & 14.8 & 25.7 & 2.5 & 23.5 & 33.5 \\
\hline Diet $\mathrm{C}$ & 98.3 & 14.2 & 18.8 & 3.5 & $5 \dot{5} .0$ & 8.5 \\
\hline Grass & 6.2 .1 & 6.8 & 51.9 & 1.5 & 34.9 & 5.0 \\
\hline $\begin{array}{l}\text { Dried Activaled Scwage } \\
\text { Sludge (DASS) }\end{array}$ & 94.0 & 27.7 & 6.9 & 4.0 & 15.2 & 40.0 \\
\hline Poultry Wastes (l'W) & 90.5 & 25.4 & 1.8 & 20.8 & 22.2 & 20.3 \\
\hline
\end{tabular}

Diet $A=$ Dict containing groundnut cake

Diet $13=$ Diet containing dricd Activated Sewage Sludge

Diet $\mathrm{C}=$ Dict containing Poultry Wastes

Three isonitrogenous rations $(14 \%$ crude protein) were compounded in such a way that groundnut cake, sewage sludge or poultry wastes served as the source of nitrogen (Table 1). Diet A (containing groundnut cake) served as control dict. The dried activated sewage sludge was collected from the Universily College Hospital, Ibadan sewage treatment plant. While the poultry droppings were collected from the layer unit of the University of Ibadan Teaching and Research Farm and air dried. Each group comprising six animals was placed on each ration fed as supplement to grass (Cynodon nlemfuensis). The goats were kept in individual metabolic cage designed for the separate collection of facces and urine. Each animal had access to fresh water daily.

The trial lasted 21 days, a 14 day adaptation period being followed by a collection period of 7 days. Animals were weighed before and alter the experimental period. Urine and faces were collected each morning before morning feeding. Urine was collected from each animal in bottles wetted with $2-3 \mathrm{ml}$ of $10 \%$ Mercuric chloride. The daily urine volume was measured and $10 r_{C}$ of the total bulked for each animal and stored in a decp freczer at $-5^{\circ} \mathrm{C}$ until required for chemical analysis. A $10 \%$ sample of the faeces voided per day was dried in a forced - draught oven at $70^{\circ} \mathrm{C}$ for 24 hours. These daily stored samples were then bulked, thoroughly mixed, ground and sub-sampled for chemical analysis.

Proximate analysis of feed and faeces samples were determined and urine samples were analysed for nitrogen (AOAC, 1984). Results were statistically craluated by analysis 

GROUNDNUT CAKE BASED DIETS AS SUPPLEMENT TO GRASS.

\begin{tabular}{|c|c|c|c|c|}
\hline \multirow[t]{2}{*}{ Parumeters } & \multirow[b]{2}{*}{$\therefore$} & \multicolumn{2}{|c|}{ Experimental Diets } & \multirow[b]{2}{*}{ Slint } \\
\hline & & $\mathbf{B}$ & c: & \\
\hline Initial I iscuecight $\left(K_{g}\right)$ & $(0,0), 3^{-1}$ & $5.5^{1}$ & $6.0^{3}$ & 0.40 \\
\hline Final loweweight (g day) & $7.22^{-1}$ & $5.44^{b}$ & $6.77^{c}$ & 0.76 \\
\hline (hanges in liveucight (g, d, & $56 . x^{1}$ & $-2.7^{\mathrm{b}}$ & $36.8^{\mathrm{c}}$ & 2.73 \\
\hline $\begin{array}{l}\text { I) matler intake from supplen } \\
\text { (g day) }\end{array}$ & $597.9^{\prime}$ & $218.3^{17}$ & $530.0^{c}$ & 6.863 \\
\hline \multicolumn{4}{|l|}{ I) maller intake ifom grass } & 5.5 \\
\hline lintal dry maller intahe (ag d.y) & $61(1+.6)^{1}$ & $321.7^{\mathrm{h}}$ & $6,00.5^{3}$ & 7.36 \\
\hline linat $-\therefore$ intike (g day ) & $14.49^{4}$ & $6 . .30^{\mathrm{h}}$ & $12.80^{\mathrm{a}}$ & 1.73 \\
\hline 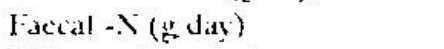 & $1.40^{4}$ & $2.75^{\mathrm{h}}$ & $1.34^{3}$ & 0.6 .3 \\
\hline L rinan $-1(y$ day $)$ & $1.16 i^{\prime \prime}$ & $2.5^{h}$ & $1.14^{: 1}$ & 11.36 \\
\hline X-butance (g'day) & $12.113^{\circ}$ & $1.144^{\mathrm{b}}$ & $10.42^{\mathrm{a}}$ & 1.20 \\
\hline N-halance ( $\mathrm{g}^{\prime}$ day $/ \mathrm{Whg}^{\mathrm{K}}{ }^{4.75}$ ) & $3.13^{: 4}$ & $0.28^{b}$ & $2.72 \mathrm{a}$ & 0.43 \\
\hline \multicolumn{5}{|c|}{ Apparent Nutrient Digestibility (\%) } \\
\hline I) & $84.619^{i t}$ & $82.13^{a}$ & $77.7^{3}$ & 3.26 \\
\hline C'rude protein & $91.33^{i t}$ & $56.64^{h}$ & $89.53^{3}$ & 2.76 \\
\hline lither exiract & $717.8^{3}$ & $82.33^{\mathrm{a}}$ & $82.9^{n}$ & 6.86 \\
\hline Crude fibre & $72.13^{3}$ & $86.0^{\mathrm{b}}$ & $69.32^{3}$ & 3.76 \\
\hline Nitrogen-frec extract & $88.89^{a}$ & $83.8^{\mathrm{a}}$ & $88.6^{\mathrm{a}}$ & 2.16 \\
\hline
\end{tabular}

abc Means along the same row with different superscripts were significantly different $(P<0.05)$.

of variance (Steel and Torrie, 1980) and the Duncan Multiple Range test was used to detect differences among means.

\section{RESULTS}

Total dry matter intake of the animals is shown in Table 3. Total dry matter intake of animals fed dicts $A$ (groundnut cake based ration) and $C$ (poultry droppings based ration) was significantly $(P<0.05)$ higher than dry matter intake of animals fed diet B. (dry activated sewage sludge based ration). Total dry matter intake of animals fed dict $\mathrm{A}$ appeared to be higher than those fed dict C, although, the differences observed were not significant $(\mathrm{P}>0.05)$.

The variations observed (Table 3) for apparent dry matter, ether extract and nitrogen-free extract digestibilities between animals fed the different diets were not significant $(\mathbf{P}>0.05)$. Crude fibre and crude protein digestibility values however varied appreciably. An appraisal of the results showed that the higher crude fibre digestibility values were recorded for goats fed diet $B$, followed by those fed diets $A$ and $C$. respectively. Crude protein digestibility values recorded for animals fed dict $B$ were significantly $(\mathrm{P}<0.05)$ lower than thosic led diets $\mathrm{A}$ and $\mathrm{C}$.

Table 3 shows the summary of nitrugen utilization by the goats. Animals fed dicts $A$ and $\mathrm{C}$ had higher $(\mathrm{P}<0.05)$ total nitrogen intake than those fed dict $\mathrm{B}$. Nitrogen balance values, (g/day and $\mathrm{g} / \mathrm{day} / \mathrm{WKg}^{0.75}$ ) were lower $(P<0.05)$ for animals fed diet $B$ compared with those fed diets $A$ and $C$. However, values recorded for weight gains, nitrogen balance ( $g /$ day and $g /$ dayWKg ${ }^{0.75}$ ) were higher for animals fed dief $A$ than those fed diet $c$. Animals on diet B, were loosing weight at the ratc of $2.7 \mathrm{~g} / \mathrm{day}$.

\section{DISCUSSION}

The dry matter $(62.1 \%)$ and crude protein $(6.8 \%)$ contents recorded for the gaint star grass (Cynoton nlemfucnsis) in the present study were in agreement with values obtained in similar studies (Akinsoyinu, 1974) while the crude fibre content was higher. This is probably due to differences in the stage of maturity of the grass as at the time of harvest, because fibre content of forage tend 10 
increase as forage matures and lignification increases (Olubajo and Akcn'Ova, 1985; Cleale and Bull, 1986).

Animals fed groundnut cake and poultry wastes based rations had higher dry matter intake than those fed the dried activated sewage sludge based ration. This suggests that the diet containing dried activated sewage sludge was not palatable, probably due to its high ash content. However, values observed for dry matter intake by the goats from concentrate supplements were higher than from grass. This suggests that the goats prefer the supplement diets to grass, since they had an unrestricted access to both grass and the concentrate supplements.

Animals fed ration containing dried activated sewages sludge appeared to have higher crude fibre digestibility values compared to those fed the other diets. This is probably due to the lower dry matter intake of animals fed dricd activated sewage sludge based diets resulting in longer exposure time of feed to rumen fermentation.

Animals on groundnut cake based ration had higher values for weight gains $(56.8 \mathrm{~g} /$ day) than those fed ration containing poultry wastes ( $36.8 \mathrm{~g} /$ day). This tends to agree with the findings of Abasiekong (1987) and suggests that groundnut cake is a better source of nitrogen for young goats than poultry wastes. However, the values recorded for weight gains for goats fed dicts containing poultry wastes in this study is higher than the value of $28.4 \mathrm{~g} /$ day recorded by Adebowale and Taiwo (1996) for WAD goats fed diets containing 15 percent poultry litter. Four of the animals fed dried activated sewage sludge based ration had negative nitrogen balance values, resulting from high urinary nitrogen excretion. This suggests inadequate energy intake resulting in the mobilisation of tissue proteins to provide energy.

The result of this study suggests poor intake of ration containing dricd activated sewage sludge by growing goats. However, the inclusion of poultry wastes up $1042 \%$ has no adverse effect on feed intake, nutricnt utilization and health of growing goats, as no hcalth problem was observed during the experimental period. This agrees with the $40 \%$ maximum level of inclusion of poultry waste recommended by other workers (Taiwo ct al 1995) in the ration of West African dwarf shecp.

\section{REFERENCES}

ABASIEKONG, S.F. (1987). "Effect of supplementary urea, poultry waste and groundnut cake on growth, feed intake and nutrient digestibility of West African dwarf goat fed ccreal residue based diets under practical tropical conditions". A paper presented at the 12th Annual Conference of the Nig. Soc. of Anim. Prod., University of Ibadan.

ADEGBOLA, A.A., SMITH, O.B. and OKEUDO, N.J. (1990)- "Response of WAD sheep fed cassava peels and poultry manure based diets". In: utilization of research results on forages and Agricultural by-product materials as animal feed resources in Africa. (Eds. Dzowela, B.H., Said A.A. Wondem Agenehu, A. and Kategile, J.H.) ILCA Addis Ababa pp. 357 - 366.

ADEBOWALE, E.A. and TAIWO, A.A. (1996)

"Utilization of crop residues and agro-industrial by-products as complete diets for West African dwarf sheep and goats. Nig. J. Anim. Prod. 23(2) 153 - 160.

ADEYEMO, A.I. (1984) "Effects of the replacement of groundnut cake with poultry droppings on feed intake, digestibility of nutrients and weight gain of sheep". M.Sc. Thesis: University of Ibadan.

AKINSOYINU, A.O. (1974) "Studies on protein and energy utilization of West African dwarf goats". Ph.D. Thesis: University of Ibadan.

A.O.A.C. (1984): Official Methods of Analysis 14th Ed. Washington D.C.

BELEWU, M.A. and ADENEYE, J.A. (1996) The effects of broiler litter as protein source on the performance of Bunaji (White Fulani) 
UTILIZATION OF SEWAGE SLUDGE AND POULTRY DROPPINGS BY WAD GOATS

bull calves." Nig. J. Anim. Prod: 23(1) 66 - 71.

BERTRAND, A. (1980). "Effect of dried digested sludge on corn grown on soil treated with liquid digested sludge on performance, Carcass quality and tissuc residuc in beer steers". J. Anim. Sc. 50: 1 - 36.

CLEALE, R.M. and BULL, L.S. (1986). "Effect of forage maturity on ration digestibility and production by dairy cows". J. Dairy Sc. 69: 1587 - 1594.

HACKLER, L.R., NEUM ANN A.L., HATFIELD E.E. and JOHNSON B.C. (1957). "Dried Activated Sewage Sludge as nitrogen source for ruminants". J. Anim. Sci. 16 (4) 1090 (Abstr.)

HAMBLIN, D.C. (1980). "Commercially processing and selling poultry waste as feed ingredients". J. Anim. Sci. 50 (2) 342 - 344.

HARMON, B.W., FONTENOT, J.P. and WEBB K.E. (1975). "Ensiled broiler litter and corn forage 2. Digestibility, nitrogen utilization and palatability by sheep". J. Anim. Sci. 40: 156 - 161.

KANE AND P, ALIEV, (1981): "Meals of dried
Pouitry litter and pigs faeces for fattening weancd lambs". J. Anim. Sci. 36: 22 - 28.

OLUBAJO, F.O and AKENOVA M.E. (1985). "The voluntary intake and digestibility of sheep on Pennisetum Purpureum (SHUM) and of threc interspecific F1 hybrid genotypes" Nig. J. Anim. Prod. 12:79.

SMITH, L.W (1973) "Recycling animal wastes as protein sources". Proc. Nat. Acad. Sci. Washington D.C. 146 - 173.

SRIDHAR, M.K.C. and PILLAI S.C. (1973). . "Protein activity in sewage sludge and effluent". Water and Waste Treatment U.K. 16: $35-42$.

STEEL, R.G.D. and TORRIE J.H. (1980). Principles and Procedure of Statistics. McGraw-Hill Book Co., New York.

TAIWO, A.A., ADEBOWALE E.A., AKINSOYINU A.O. and GREENHALGH J.F.D. (1995). "Comparative study on the use of four protein supplements by WAD sheep, Nig. J. Anim. Prod. 21: 68 - 75. 